\title{
Effects of propofol on lipopolysaccharide-induced expression and release of HMGB1 in macrophages
}

\author{
T. Wang, X.Y. Wei, B. Liu, L.J. Wang and L.H. Jiang \\ Department of Anesthesiology, the Third Affiliated Hospital, Zhengzhou University, Zhengzhou, China
}

\begin{abstract}
This study aimed to determine the effects of different concentrations of propofol (2,6-diisopropylphenol) on lipopolysaccharide (LPS)-induced expression and release of high-mobility group box 1 protein (HMGB1) in mouse macrophages. Mouse macrophage cell line RAW264.7 cells were randomly divided into 5 treatment groups. Expression levels of HMGB1 mRNA were detected using RT-PCR, and cell culture supernatant HMGB1 protein levels were detected using enzyme-linked immunosorbent assay (ELISA). Translocation of HMGB1 from the nucleus to the cytoplasm in macrophages was observed by Western blotting and activity of nuclear factor kappa-light-chain-enhancer of activated B cells (NF-kB) in the nucleus was detected using ELISA. HMGB1 mRNA expression levels increased significantly in the cell culture supernatant and in cells after $24 \mathrm{~h}$ of stimulating RAW264.7 cells with LPS (500 ng/mL). However, HMGB1 mRNA expression levels in the P2 and P3 groups, which received $500 \mathrm{ng} / \mathrm{mL}$ LPS with 25 or $50 \mu \mathrm{mol} / \mathrm{mL}$ propofol, respectively, were significantly lower than those in the group receiving LPS stimulation $(P<0.05)$. After stimulation by LPS, HMGB1 protein levels were reduced significantly in the nucleus but were increased in the cytoplasm $(P<0.05)$. Simultaneously, the activity of NF- $\kappa B$ was enhanced significantly $(P<0.05)$. After propofol intervention, HMGB1 translocation from the nucleus to the cytoplasm and NF- $\mathrm{KB}$ activity were inhibited significantly (each $\mathrm{P}<0.05$ ). Thus, propofol can inhibit the LPSinduced expression and release of HMGB1 by inhibiting HMGB1 translocation and NF-KB activity in RAW264.7 cells, suggesting propofol may be protective in patients with sepsis.
\end{abstract}

Key words: Propofol; HMGB1; LPS; RAW 264.7 cells; NF-кB

\section{Introduction}

Sepsis is a systemic inflammatory response syndrome (SIRS) that develops when the host organism immune response to severe infection by various pathogenic microorganisms in blood or tissue triggers a life-threatening wholebody inflammatory response. In clinical settings, sepsis has a higher morbidity rate than myocardial infarction and is the major cause of death for patients in intensive care units without heart disease. Sepsis in patients can be detected by identifying the pathogenic microorganism or observing highly suspicious infection foci. The occurrence and development of the disease is followed by pathological processes and eventual regulation. In recent years, although anti-infective therapy and organ function support technology have been improved greatly, the mortality rate of sepsis remains between 30 and $70 \%$. In particular, the mortality rate of patients with septic shock might be as high as $50 \%$ (1). Because of the expense of treatments and large consumption of medical resources, sepsis seriously affects the quality of human life and poses a great threat to human health.
The basic pathogenesis of sepsis not only involves the contributions of pathogenic bacterial toxins and metabolic products but also the generation and release of host inflammatory mediators. Bacterial endotoxins, host inflammatory mediators, host immune dysfunction, intestinal bacteria/endotoxin translocation, coagulopathy, and gene polymorphisms contribute concurrently to disease progression (2). Multiple factors, such as complex systemic inflammation network effects, gene polymorphisms, immune function barriers, coagulation disorders, tissue damage, and abnormal host reactions to infection by different pathogenic microorganisms and their toxins, have a close relationship with multiple systems in the host organism and pathological physiological changes in multiple organs. Among these, the excessive release of inflammatory mediators is a crucial and core mechanism in SIRS (3), and the high-mobility group box 1 protein (HMGB1) is an important late inflammatory mediator (4-7). HMGB1, a nuclear factor and secreted protein, functions as an architectural chromatin-binding

Correspondence: Lihua Jiang: <lihuajain@126.com>.

Received July 5, 2014. Accepted October 10, 2014. First published online February 24, 2015. 
factor that bends DNA and promotes protein assembly on specific DNA targets in the cell nucleus $(8,9)$. Macrophages are released into the extracellular environment after stimulation. Then, multiple receptors expressed on macrophages induce the release of early inflammatory mediators that strengthen the inflammatory cascade (10). HMGB1 can also be released extracellularly as a late mediator of lethality in sepsis, as well as after necrotic death (11), thus, the role of HMGB1 is crucial in immunoreactions.

HMGB1 stimulates monocytes to secrete a specific subset of proinflammatory cytokines (including tumor necrosis factor [TNF]- $\alpha$ and interleukin [IL]-1) (12). Monocytes/ macrophages are stimulated by lipopolysaccharide (LPS), TNF, or IL-1, and secrete HMGB1 as a delayed response $(4,13)$. Studies have indicated that propofol (2,6-diisopropylphenol) inhibits the release of many early inflammatory cytokines in LPS-stimulated mononuclear macrophages $(14,15)$, as well as pressure-stimulated macrophage phagocytosis (16). However, the effects of propofol on the expression and release of HMGB1 in mononuclear macrophages are unclear. Based on the importance of HMGB1 in immunoreactions and the potential relationship between HMGB1 and LPS, this study aimed to investigate whether propofol has an inhibitory action on the expression and release of HMGB1 in RAW264.7 murine macrophages. The findings will provide a theoretical basis for the application of propofol in treating sepsis in clinical settings.

\section{Material and Methods}

\section{Cell culture and grouping}

RAW264.7 cells were cultured in RPMI-1640 culture solution at $37^{\circ} \mathrm{C}$ in a $5 \%-\mathrm{CO}_{2}$ incubator. The culture solution was composed of $100 \mathrm{U} / \mathrm{mL}$ penicillin, $100 \mu \mathrm{g} / \mathrm{mL}$ streptomycin, $10 \%$ fetal calf serum, and $2 \mathrm{~mol} / \mathrm{L}$ glutamine (GIn). After RAW264.7 cells had differentiated to $80 \%$, they were digested using a solution of $0.25 \%$ pancreatic enzymes and $0.02 \%$ EDTA.

Digested cells were divided into five groups: negative control group (control group), treated with $500 \mathrm{ng} / \mathrm{mL}$ LPS (LPS group), P1 group treated with $500 \mathrm{ng} / \mathrm{mL}$ LPS and an equal quantity of fat emulsion (a volume of fat emulsion comparable to low dose propofol), P2 group treated with $500 \mathrm{ng} / \mathrm{mL}$ LPS and $25 \mu \mathrm{mol} / \mathrm{mL}$ propofol, and P3 group treated with $500 \mathrm{ng} / \mathrm{mL}$ LPS and $50 \mu \mathrm{mol} / \mathrm{mL}$ propofol. The composition of fat emulsion included fatty acids and triglycerides (Xian Janssen Pharmaceutical Ltd., China). After $24 \mathrm{~h}$ incubation, these cultured cells were used for further experiments.

Propofol was obtained from AstraZeneca Pharmaceuticals (UK). RPMI-1640 culture medium was obtained from Shanghai Enzyme-linked Biological Technology Company (China). LPS from Escherichia coli 011:B4 was obtained from Sigma-Aldrich Company (USA). Fetal calf serum was obtained from Shanghai Xinran Biological Technology Company (China).

\section{Detection of relative expression levels of HMGB1 RNA}

Total RNA from RAW264.7 cells in each group was isolated with Trizol (Invitrogen, USA). The $A_{260} / A_{280}$ value of RNA was determined to be 1.8-2.0 by measuring the absorbance of isolated RNA samples at wavelengths of 260 and $280 \mathrm{~nm}$ using a spectrophotometer. The total RNA yield was $2 \mu \mathrm{g}$, which was then transcribed into cDNA using reverse transcription kits. The primers for amplification of mouse HMGB1 and $\beta$-actin were obtained from Invitrogen (China). The HMGB1 primer sequences were: sense $5^{\prime}-$ CAC CGT GGG ACT ATT AGG AT-3' and antisense 5'GCT CAC ACT TTT GGG GAT AC-3'. The $\beta$-actin primer sequences were: sense 5'-CCT CTA TGC CAA CAC AGT3', antisense 5'-AGC CAC CAA TCC ACA CAG-3'. The amplification conditions were as follows: $95^{\circ} \mathrm{C} / 5 \mathrm{~min}, 95^{\circ} \mathrm{C} /$ $5 \mathrm{~s}, 60^{\circ} \mathrm{C} / 30 \mathrm{~s}, 95^{\circ} \mathrm{C} / 15 \mathrm{~s}, 72^{\circ} \mathrm{C} / 10 \mathrm{~s}$, and $95^{\circ} \mathrm{C} / 15 \mathrm{~s}(40$ cycles). PCR products (the amplified sequences were 181 and $155 \mathrm{bp}$ for HMGB1 and $\beta$-actin, respectively) were validated using agarose gel electrophoresis and visualized under a UV lamp. The relative expression levels of HMGB1 and $\beta$-actin were estimated based on the absorbance ratios using the Tanon $4.00 \mathrm{gel}$ image processing system (China).

\section{Detection of HMGB1 protein levels}

Total protein in cells from each group was extracted according to the NE-PER Nuclear Protein Extraction kit instructions (Thermo Scientific Company, USA). In particular, cells were washed first with PBS, collected using a cell scraper, centrifuged at $500 \mathrm{~g}$ for $5 \mathrm{~min}$, and the cell pellets collected. To each $20 \mu \mathrm{L}$ cell pellet, $200 \mu \mathrm{L}$ PMSF and cytoplasmic protein extraction reagent I were added, and samples were vibrated vigorously for $15 \mathrm{~s}$ before incubation in an ice-bath for $10 \mathrm{~min}$. Cytoplasmic protein extraction reagent II was added and vigorously vibrated for $5 \mathrm{~s}$, followed by incubation in an in ice-bath for $1 \mathrm{~min}$. Treated cells were centrifuged at $160,000 \mathrm{~g}$ for $5 \mathrm{~min}$ at $4{ }^{\circ} \mathrm{C}$. The supernatants, which contained cell cytoplasmic proteins, were collected in precooled Eppendorf (EP) tubes. Overall, $100 \mu \mathrm{L}$ nucleoprotein extraction reagent and PMSF were added to the remaining cell pellets, which were vibrated vigorously for $15 \mathrm{~s}$ before incubation in an ice-bath for $10 \mathrm{~min}$. This process was repeated 4 times, for a total of $40 \mathrm{~min}$. Treated cell pellets were centrifuged at 160,000 $\mathrm{g}$ for $10 \mathrm{~min}$ at $4^{\circ} \mathrm{C}$. The supernatants containing cell nuclear proteins were collected in precooled EP tubes.

The protein levels of the samples were measured using a BCA kit (Solarbio Science, China). Samples mixed with a double amount of loading buffer were heated at $95^{\circ} \mathrm{C}$ for $5 \mathrm{~min}$ and then electrophoresed through a $15 \%$ polyacrylamide gel. The proteins were transferred to a nitrocellulose membrane via an electric drill, and the membranes were blocked for $1.5 \mathrm{~h}$ in Tris-buffered saline and Tween-20 buffer with $5 \%$ skim milk powder. Rabbit anti-HMGB1 polyclonal antibody (Abcam Company, USA; 1:300) was added to the blocking solution and incubated with vibration for $2 \mathrm{~h}$. 
Membranes were washed 3 times (5 min each time) before sheep anti-rabbit horseradish peroxidase labeling antibody (Shuji Biological Technology Company, China) was added $(1: 1000)$ and incubated with vibration for $1 \mathrm{~h}$. Finally, the membranes were washed 3 times ( 5 min each time). Simultaneously, for normalized comparisons, anti- $\beta$-actin antibody (1:1000) and anti-histidine H3.1 antibody (Santa Cruz Company, USA; 1:1000) were used as internal controls for nuclear and cytoplasmic proteins, respectively. Bands of proteins and internal controls were scanned to determine their absorbance and analyzed using GeneTools Gel imaging analysis software (Syngene, USA). The levels of target protein and control proteins were determined and further statistical analyses were performed.

\section{NF-кB activity in cell nuclear fractions}

Proteins in cell nuclear fractions were obtained from each group and were used to detect nuclear factor kappalight-chain-enhancer of activated $B$ cells $(N F-\kappa B)$ activity using an NF-kB kit (Active Motif Company, USA).

\section{Statistical analysis}

The SPSS v13.0 software was used to perform statistical analysis. Data are reported as means $\pm S D$. ANOVA was used to estimate the difference among multiple groups, and the $t$-test was used to estimate the difference between two groups. If the $P$ value was less than 0.05 , the differences were considered statistically significant.

\section{Results}

\section{HMGB1 mRNA expression levels were high after LPS stimulation}

The expression level of HMGB1 mRNA in the control group was lower than in the other groups, while HMGB1 mRNA was highly expressed at $24 \mathrm{~h}$ after LPS stimulation $(P<0.05)$. In contrast, treatment with propofol in the $P 2$ and P3 groups significantly inhibited HMGB1 mRNA expression levels in mouse macrophages $(P<0.05$; Figure $1 A$ and $B)$.

\section{HMGB1 protein levels were increased significantly after LPS stimulation}

Compared with the control group, HMGB1 protein levels were increased significantly at $24 \mathrm{~h}$ after LPS stimulation $(P<0.05)$. Fat emulsion had no significant inhibitory effect on HMGB1 expression or release in the $\mathrm{P} 1$ group $(\mathrm{P}>0.05)$. However, propofol showed a significant inhibition of HMGB1 expression and release in the $\mathrm{P} 2$ group $(\mathrm{P}<0.05)$. A similar level of inhibition was detected in the $P 3$ group $(P<0.01$; Figure $1 \mathrm{C}$ and $\mathrm{D}$ ). The change in the level of HMGB1 protein in the supernatant from each group was consistent with a change of HMGB1 mRNA expression levels.
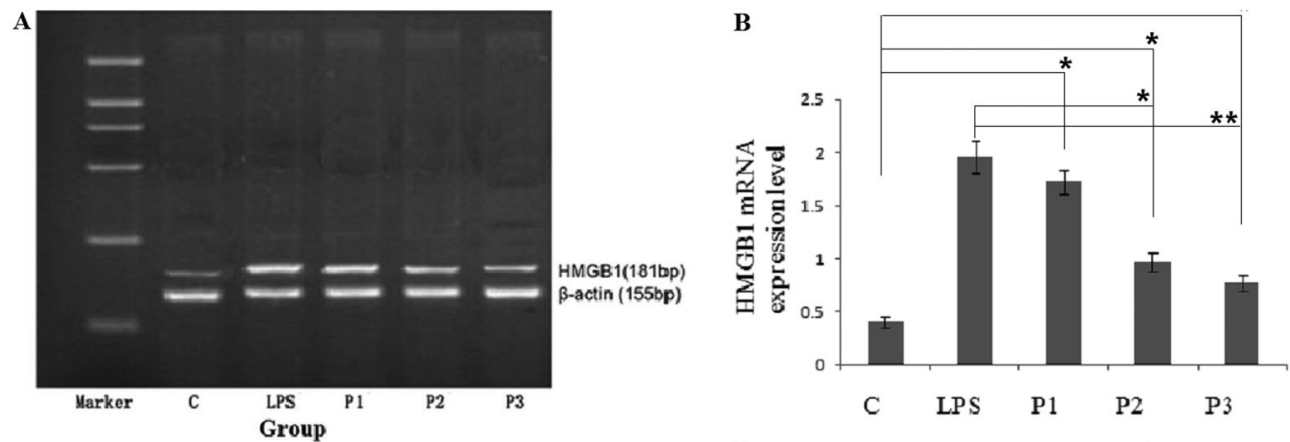

C

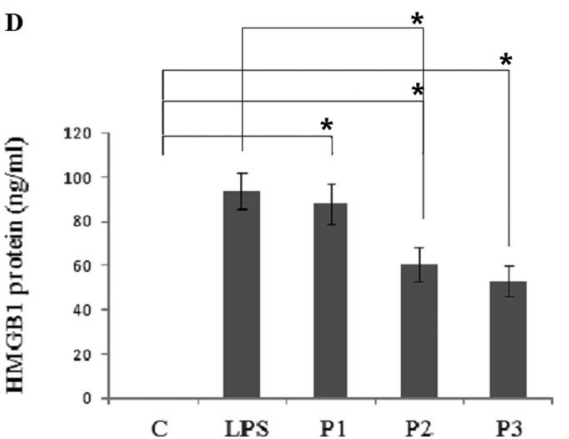

Figure 1. Gel electrophoresis of HMGB1 mRNA and HMGB1 protein levels in each group. $A, B$, Gel electrophoresis of $H M G B 1$ mRNA; $C$, HMGB1 protein levels in cell nucleus and cytoplasm; $D$, HMGB1 protein levels in cytoplasm. ${ }^{*} \mathrm{P}<0.05 ;{ }^{* *} \mathrm{P}<0.001$ (ANOVA) Groups: C, negative control; LPS, treated with $500 \mathrm{ng} / \mathrm{mL}$ lipopolysaccharide (LPS); P1, treated with $500 \mathrm{ng} / \mathrm{mL}$ LPS and equal quantity of fat emulsion; P2, treated with $500 \mathrm{ng} / \mathrm{mL}$ LPS and $25 \mu \mathrm{mol} / \mathrm{mL}$ propofol; P3, treated with $500 \mathrm{ng} / \mathrm{mL} \mathrm{LPS}$ and $50 \mu \mathrm{mol} / \mathrm{mL}$ propofol. HMGB1: high-mobility group box 1 protein. 
Table 1. HMGB1 protein levels in cell nucleus and cytoplasm in mouse macrophages.

\begin{tabular}{lcc}
\hline Groups & HMGB1 in nucleus & HMGB1 in cytoplasm \\
\hline C & $0.280 \pm 0.037$ & $0.077 \pm 0.011$ \\
LPS & $0.048 \pm 0.06^{\mathrm{a}}$ & $0.161 \pm 0.015^{\mathrm{a}}$ \\
P1 & $0.063 \pm 0.008^{\mathrm{a}}$ & $0.184 \pm 0.026^{\mathrm{a}}$ \\
P2 & $0.097 \pm 0.010^{\mathrm{ab}}$ & $0.148 \pm 0.015^{\mathrm{ab}}$ \\
P3 & $0.160 \pm 0.031^{\mathrm{ac}}$ & $0.111 \pm 0.017^{\mathrm{ac}}$ \\
\hline
\end{tabular}

Data are reported as means $\pm S D(n=9)$. Groups: $C$, negative control; LPS, treated with $500 \mathrm{ng} / \mathrm{mL}$ lipopolysaccharide (LPS); $\mathrm{P} 1$, treated with $500 \mathrm{ng} / \mathrm{mL}$ LPS and equal quantity of fat emulsion; P2, treated with $500 \mathrm{ng} / \mathrm{mL}$ LPS and $25 \mu \mathrm{mol} / \mathrm{mL}$ propofol; P3, treated with $500 \mathrm{ng} / \mathrm{mL}$ LPS and $50 \mu \mathrm{mol} / \mathrm{mL}$ propofol. HMGB1, high-mobility group box 1 protein. ${ }^{a} \mathrm{P}<0.05$, compared with $\mathrm{C}$ group; ${ }^{\mathrm{b}} \mathrm{P}<0.05,{ }^{\mathrm{C}} \mathrm{P}<0.01$, compared with LPS group (Student's $t$-test).

Propofol intervention reversed HMGB1 translocation from the nucleus to cytoplasm after LPS stimulation

Nuclear and cytoplasmic HMGB1 protein levels were detected using Western blotting. Nuclear HMGB1 protein levels were reduced significantly after LPS stimulation $(P<0.05)$, whereas nuclear levels were increased significantly after propofol intervention $(P<0.05$; Figure $1 C$ and $D$, and Table 1). In contrast, cytoplasmic HMGB1 protein levels were increased significantly after LPS stimulation $(P<0.05)$, whereas cytoplasmic levels were reduced significantly after propofol intervention $(\mathrm{P}<0.05$; Figure $1 \mathrm{C}$ and Table 1). HMGB1 translocated from the nucleus to the cytoplasm after LPS stimulation, but propofol intervention inhibited this translocation.

\section{Propofol inhibited increased activity induced by LPS stimulation}

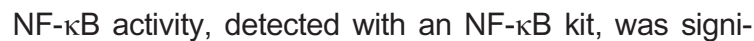
ficantly increased after LPS stimulation $(P<0.05)$, but was reduced after propofol intervention $(P<0.05$; Table 2). Thus, propofol inhibited increased NF- $\mathrm{KB}$ activity resulting from LPS stimulation.

\section{Discussion}

Typical reactions of sepsis pathogenesis include the release of early proinflammatory factors (TNF- $\alpha$ and IL-1) and late proinflammatory factors (HMGB1) that excessively activate the host systemic inflammatory response to bacterial infections. Excessive generation of these proinflammatory factors can lead to very serious complications, including whole-body blood capillary leak syndrome, damage of tissues, and fatal multi-organ failure $(17,18)$. As such, intervention against the over-activity of proinflammatory mediators has been an effective means to treat sepsis. Neutralizing early proinflammatory factors such as TNF- $\alpha$ and IL-1 inhibited the process of septic shock in animal
Table 2. NF- $\kappa B$ activity in cell nucleus of mouse macrophages.

\begin{tabular}{ll}
\hline Groups & NF-kB activity \\
\hline C & $100.28 \pm 8.79$ \\
LPS & $324.83 \pm 39.68^{\mathrm{a}}$ \\
P1 & $318.34 \pm 35.45^{\mathrm{a}}$ \\
P2 & $235.48 \pm 25.65^{\mathrm{ab}}$ \\
P3 & $176.78 \pm 20.54^{\mathrm{ac}}$ \\
\hline
\end{tabular}

Data are reported as means $\pm S D(n=9)$. Groups: $C$, negative control; LPS, treated with $500 \mathrm{ng} / \mathrm{mL}$ lipopolysaccharide (LPS); $\mathrm{P} 1$, treated with $500 \mathrm{ng} / \mathrm{mL}$ LPS and equal quantity of fat emulsion; P2, treated with $500 \mathrm{ng} / \mathrm{mL}$ LPS and $25 \mu \mathrm{mol} / \mathrm{mL}$ propofol; P3, treated with $500 \mathrm{ng} / \mathrm{mL}$ LPS and $50 \mu \mathrm{mol} / \mathrm{mL}$ propofol. NF-kB: nuclear factor kappa-light-chain-enhancer of activated B cells. ${ }^{\mathrm{a}} \mathrm{P}<0.05$, compared with $\mathrm{C}$ group; ${ }^{\mathrm{b}} \mathrm{P}<0.05$, ${ }^{\mathrm{C}} \mathrm{P}<0.01$, compared with LPS group (Student's $t$-test).

models (17), but targeting these factors showed poor clinical effects in critical patients (19). One major reason for this clinical failure may be caused by a shorter therapeutic window of intervention against early inflammatory mediators. HMGB1 protein, a late proinflammatory factor that can induce sepsis, is closely associated with morbidity and fatality rates $(4,20)$. HMGB1 is a DNA-binding protein in the cell, which is released into the extracellular environment after macrophages are activated. As a proinflammatory factor, extracellular HMGB1 induces plasminogen activator, stimulates the generation of other proinflammatory factors (TNF- $\alpha, \mathrm{IL}-1 \beta$, and IL-8), and increases the permeability of epithelial cells (21-23). Treatment targeting HMGB1 can significantly improve the survival rate of rats with sepsis and can reduce multiple organ dysfunctions. Moreover, targeting HMGB1 has good clinical effects in patients with critical illness. Taken together, inhibition of the late proinflammatory factor HMGB1 is an effective method to treat sepsis (24).

Propofol is widely used for the induction and maintenance of anesthesia in clinical settings. It is a novel, fastand short-acting intravenous anesthetic in critical patients in the ICU. As an important narcotic, propofol can reduce the occurrence of awareness, protect the heart in patients with surgery $(25)$, has the potential to treat sepsis $(26,27)$, and can protect important organs in ischemia reperfusion injury (28-30). Some reports suggest that propofol can inhibit the release of many early inflammatory cytokines in mononuclear macrophages after LPS stimulation (14-16). However, it is unclear whether propofol inhibits the expression and release of HMGB1 in mononuclear macrophages. In this study, mouse RAW264.7 macrophages were used to study the anti-inflammatory mechanism of propofol, specifically by observing the effects of different concentrations of propofol on the expression of HMGB1 mRNA and release of HMGB1 protein in culture supernatants of LPSstimulated RAW264.7 cells. We found that in RAW264.7 cells induced by LPS the characteristics of HMGB1 mRNA expression and of HMGB1 protein release were similar to 
those described by others (31-33) (Figure $1 \mathrm{~A}$ and $\mathrm{B}$ ). Intervention with either $25 \mu \mathrm{mol} / \mathrm{mL}$ or $50 \mu \mathrm{mol} / \mathrm{mL}$ propofol inhibited the expression and release of HMGB1 in LPSinduced RAW264.7 cells (Figure 1C and Table 1). Although there was no significant difference between the two groups (P2 and P3), intervention with $50 \mu \mathrm{mol} / \mathrm{mL}$ propofol had a stronger inhibitory effect on the release of HMGB1 protein than intervention with $25 \mu \mathrm{mol} / \mathrm{mL}$ propofol (Table 2); however, this simultaneously increases cardiovascular side effects associated with an increased dosage. As such, $25 \mu \mathrm{mol} / \mathrm{mL}$ propofol may be a better dose for intervention in clinical settings based on the side effects observed at higher doses.

By observing LPS and P3 groups in RAW264.7 cells at $23 \mathrm{~h}$ after LPS stimulation, we observed that HMGB1 protein was translocated from the cell nucleus to the cytoplasm. Western blotting showed that the protein band from the cytoplasmic fraction of LPS-stimulated cells had an increased density, while the density of the protein band from the nuclear fraction was thinner (Figure $1 A$ and $B$ ). Compared with the LPS treated group, the density of the HMGB1 protein band from the propofol treated group was

\section{References}

1. Balk RA. Severe sepsis and septic shock. Definitions, epidemiology, and clinical manifestations. Crit Care Clin 2000; 16: 179-192, doi: 10.1016/S0749-0704(05)70106-8.

2. Kansagara D, Fu R, Freeman M, Wolf $F$, Helfand M. Intensive insulin therapy in hospitalized patients: a systematic review. Ann Intern Med 2011; 154: 268-282, doi: 10.7326/0003-4819154-4-201102150-00008.

3. Hotchkiss RS, Karl IE. The pathophysiology and treatment of sepsis. N Engl J Med 2003; 348: 138-150, doi: 10.1056/ NEJMra021333.

4. Wang $\mathrm{H}$, Bloom $\mathrm{O}$, Zhang M, Vishnubhakat JM, Ombrellino $\mathrm{M}$, Che J, et al. HMG-1 as a late mediator of endotoxin lethality in mice. Science 1999; 285: 248-251, doi: 10.1126/ science.285.5425.248.

5. Valdes-Ferrer S, Blanc L, Li JH, Sangeeta C, Tracey K. HMGB1 impairs erythropoiesis during sepsis (P3163). J Immunol 2013; 190: 43.43.

6. Wang H, Ward MF, Sama AE. Targeting HMGB1 in the treatment of sepsis. Expert Opin Ther Targets 2014; 18: 257268, doi: 10.1517/14728222.2014.863876.

7. Valdés-Ferrer SI, Blanc L, Didier S, Liu JM, Lipton JM, Chavan $\mathrm{SC}$, et al. HMGB1 is a key modulator of stress erythropoiesis during sepsis. Blood 2013; 122: 8.

8. Lotze MT, Tracey KJ. High-mobility group box 1 protein (HMGB1): nuclear weapon in the immune arsenal. Nat Rev Immunol 2005; 5: 331-342, doi: 10.1038/nri1594.

9. Jiang W, Pisetsky DS. Mechanisms of disease: the role of high-mobility group protein 1 in the pathogenesis of inflammatory arthritis. Nat Clin Pract Rheumatol 2007; 3: 52-58, doi: 10.1038/ncprheum0379.

10. van Zoelen MA, Yang $H$, Florquin S, Meijers JC, Akira S, Arnold B, et al. Role of toll-like receptors 2 and 4 , and the receptor for advanced glycation end products in high-mobility thinner, suggesting propofol inhibited HMGB1 translocation under LPS stimulation. LPS can also activate NF-kB and lead to further expression and release of HMGB1 in RAW264.7 cells. In the control group, NF- $\mathrm{B}$ formed inactive complexes with the inhibitor protein, $I \kappa B$, in the cytoplasm. When cells are stimulated by LPS, $I \kappa B$ is phosphorylated and degraded. Dissociated NF- $\mathrm{B} B$ is transferred to the cytoplasm, where it further induces HMGB1 gene transcription. LPS also activates the Toll-like receptor (TLR)4-NF- $\mathrm{B}$ s signal transduction pathway through LPS-LBP-CD14 complexes, as well as promoting gene transcription and gene expression of many cytokines.

Taken together, this study indicates that propofol can significantly reduce the release of HMGB1 protein in mouse macrophages stimulated by LPS, inhibit the expression of HMGB1 mRNA, and inhibit the activity of NF-кB. These results provide experimental evidence for the application of propofol for the treatment of sepsis and other inflammatory diseases. However, further studies should be performed in vivo to validate whether propofol can inhibit systemic inflammatory responses induced by endotoxins and protect against multi-organ dysfunction. group box 1-induced inflammation in vivo. Shock 2009; 31: 280-284, doi: 10.1097/SHK.0b013e318186262d.

11. Tsung A, Sahai R, Tanaka H, Nakao A, Fink MP, Lotze MT, et al. The nuclear factor HMGB1 mediates hepatic injury after murine liver ischemia-reperfusion. J Exp Med 2005; 201: 1135-1143, doi: 10.1084/jem.20042614.

12. Muller S, Scaffidi P, Degryse B, Bonaldi T, Ronfani L, Agresti $A$, et al. New EMBO members' review: the double life of HMGB1 chromatin protein: architectural factor and extracellular signal. EMBO J 2001; 20: 4337-4340, doi: 10.1093/ emboj/20.16.4337.

13. Wang $\mathrm{H}$, Vishnubhakat JM, Bloom $\mathrm{O}$, Zhang $\mathrm{M}$, Ombrellino M, Sama A, et al. Proinflammatory cytokines (tumor necrosis factor and interleukin 1) stimulate release of high mobility group protein-1 by pituicytes. Surgery 1999; 126: 389-392, doi: 10.1016/S0039-6060(99)70182-0.

14. Zhan J, Zhang ZZ, Chen C, Chen K, Wang YL. Penehyclidine hydrochloride attenuates LPS-induced iNOS production by inhibiting p38 MAPK activation in endothelial cells. Mol Biol Rep 2012; 39: 1261-1265, doi: 10.1007/s11033011-0857-4.

15. Zhan J, Wang Y, Wang C, Li J, Zhang Z, Jia B. Protective effects of penehyclidine hydrochloride on septic mice and its mechanism. Shock 2007; 28: 727-732.

16. Ye HH, Wu KJ, Fei SJ, Zhang XW, Liu HX, Zhang JL, et al. Propofol participates in gastric mucosal protection through inhibiting the toll-like receptor-4/nuclear factor kappa-B signaling pathway. Clin Res Hepatol Gastroenterol 2013; 37: e3-15, doi: 10.1016/j.clinre.2012.03.004.

17. Czura CJ, Yang H, Amella CA, Tracey KJ. HMGB1 in the immunology of sepsis (not septic shock) and arthritis. Adv Immunol 2004; 84: 181-200, doi: 10.1016/S0065-2776(04) 84005-7. 
18. Scaffidi $P$, Misteli $T$, Bianchi ME. Release of chromatin protein HMGB1 by necrotic cells triggers inflammation. Nature 2002; 418: 191-195, doi: 10.1038/nature00858.

19. Abraham E, Anzueto A, Gutierrez G, Tessler S, San Pedro $\mathrm{G}$, Wunderink R, et al. Double-blind randomised controlled trial of monoclonal antibody to human tumour necrosis factor in treatment of septic shock. NORASEPT II Study Group. Lancet 1998; 351: 929-933, doi: 10.1016/S0140-6736(05) 60602-2.

20. Bae JS. Role of high mobility group box 1 in inflammatory disease: focus on sepsis. Arch Pharm Res 2012; 35: 15111523, doi: 10.1007/s12272-012-0901-5.

21. Ulloa L, Ochani M, Yang H, Tanovic M, Halperin D, Yang R, et al. Ethyl pyruvate prevents lethality in mice with established lethal sepsis and systemic inflammation. Proc Natl Acad Sci U S A 2002; 99: 12351-12356, doi: 10.1073/ pnas. 192222999.

22. Yang H, Ochani M, Li J, Qiang X, Tanovic M, Harris HE, et al. Reversing established sepsis with antagonists of endogenous high-mobility group box 1 . Proc Natl Acad Sci U S A 2004; 101: 296-301, doi: 10.1073/pnas.2434651100.

23. Tang J, Deng $P$, Jiang $Y$, Tang $Y$, Chen B, Su L, et al. Role of HMGB1 in propofol protection of rat intestinal epithelial cells injured by heat shock. Cell Biol Int 2013; 37: 262-266, doi: 10.1002/cbin.10040.

24. Wang $\mathrm{H}$, Liao $\mathrm{H}$, Ochani $\mathrm{M}$, Justiniani $\mathrm{M}$, Lin $\mathrm{X}$, Yang L, et al. Cholinergic agonists inhibit HMGB1 release and improve survival in experimental sepsis. Nat Med 2004; 10: 12161221, doi: $10.1038 / \mathrm{nm} 1124$

25. Tao MZ, Liu HM, Zhan P, Xia ZY. Effects of glucose concentration on propofol cardioprotection against ischemiareperfusion injury in isolated rat hearts. FASEB J 2013; 27: lb620.

26. Bao HG, Li S. Effects of propofol on the outcomes of rats with sepsis. J Surg Res 2011; 168: e111-e115, doi: 10.1016/j.jss. 2010.12.034

27. Li S, Bao H, Han L, Liu L. Effects of propofol on early and late cytokines in lipopolysaccharide-induced septic shock in rats. $J$ Biomed Res 2010; 24: 389-394, doi: 10.1016/S1674-8301(10) 60052-8.

28. Vasileiou I, Kalimeris K, Nomikos T, Xanthopoulou MN, Perrea D, Agrogiannis G, et al. Propofol prevents lung injury following intestinal ischemia-reperfusion. J Surg Res 2012; 172: 146-152, doi: 10.1016/j.jss.2010.07.034.

29. Ye L, Luo CZ, McCluskey SA, Pang QY, Zhu T. Propofol attenuates hepatic ischemia/reperfusion injury in an in vivo rabbit model. J Surg Res 2012; 178: e65-e70, doi: 10.1016/ j.jss.2012.01.037.

30. Cui D, Wang L, Qi A, Zhou Q, Zhang X, Jiang W. Propofol prevents autophagic cell death following oxygen and glucose deprivation in PC12 cells and cerebral ischemia-reperfusion injury in rats. PLoS One 2012; 7: e35324, doi: 10.1371/ journal.pone. 0035324 .

31. Wu CX, Sun H, Liu Q, Guo H, Gong JP. LPS induces HMGB1 relocation and release by activating the NF-kappaB-CBP signal transduction pathway in the murine macrophage-like cell line RAW264.7. J Surg Res 2012; 175: 88-100, doi: 10.1016/j.jss.2011.02.026.

32. Liu Z, Zhang J, Huang X, Huang L, Li S, Wang Z. Magnesium sulfate inhibits the secretion of high mobility group box 1 from lipopolysaccharide-activated RAW264.7 macrophages in vitro. J Surg Res 2013; 179: e189-e195, doi: 10.1016/j.jss. 2012.02.012.

33. Yang Y, Wang J, Yang Q, Wu S, Yang Z, Zhu H, et al. Shikonin inhibits the lipopolysaccharide-induced release of HMGB1 in RAW264.7 cells via IFN and NF-kappaB signaling pathways. Int Immunopharmacol 2014; 19: 81-87, doi: 10.1016/j.intimp. 2014.01.003. 